\title{
Ocean Acidification: Calcifying Marine Organisms ${ }^{1}$
}

\author{
Joseph Henry, Joshua Patterson, and Lisa Krimsky²
}

This document is one in a series on ocean acidification (OA). The series Introduction, Ocean Acidification: An Introduction, contains a general overview and information on the causes and chemistry of OA. Because OA is very large-scale and complex, each document in the series addresses a specific aspect of this issue. Florida, with an extensive coastline and deep cultural and economic ties to marine resources, will be directly affected by changes in seawater chemistry. Thus, each topic in the series also highlights information of specific relevance for Florida.

\section{Introduction}

Rising atmospheric carbon dioxide $\left(\mathrm{CO}_{2}\right)$ concentration leads to ocean acidification, which is a threat to coastal and marine ecosystems and organisms. As atmospheric $\mathrm{CO}_{2}$ rises, $\mathrm{CO}_{2}$ is driven into the ocean via diffusion. When $\mathrm{CO}_{2}$ combines with seawater $\left(\mathrm{H}_{2} \mathrm{O}\right)$, it makes carbonic acid $\left(\mathrm{H}_{2} \mathrm{CO}_{3}\right)$. Carbonic acid then breaks down to form a hydrogen ion $(\mathrm{H}+)$ and a bicarbonate ion $\left(\mathrm{HCO}_{3}^{-}\right)$. Excess hydrogen ions building up over time result in decreased seawater $\mathrm{pH}$. Furthermore, the excess hydrogen ions combine with carbonate ions in the water, resulting in fewer available carbonate ions for marine calcifiers. Calcifiers are organisms that can synthesize calcium carbonate (from calcium and bicarbonates or carbonates) into shells and other skeletal structures. Carbonate ions are an essential element for marine calcifiers, and their decreased availability in marine ecosystems is a concern. Declining seawater
$\mathrm{pH}$ and reduced availability of carbonate ions have been linked to unfavorable impacts on physiology, behavior, and calcification rates of marine organisms. Coastal Florida boasts an abundance and diversity of calcifying organisms that are vulnerable to altered seawater carbonate chemistry that results from increased atmospheric $\mathrm{CO}_{2}$ levels. This publication will focus on the impacts of ocean acidification on calcification, the process by which calcifying organisms produce calcium carbonate $\left(\mathrm{CaCO}_{3}\right)$ to build their skeletons, and the impacts of ocean acidification on calcification in corals, bivalves, echinoderms, and planktonic organisms (Figure 1). Furthermore, this publication will explore areas in need of future study as scientists seek to determine the real-world implications and impacts of ocean acidification on the calcification process performed by some of the most important species in the marine environment.

\section{Impacts on Corals}

Florida is home to one of the largest coral reef systems in the world and the only barrier coral reef in the continental United States. The Florida Reef Tract stretches 360 linear miles and protects Florida's coastline. According to a 2013 analysis, the reefs of southeast Florida generate $\$ 3.33$ billion a year and create 70,000 jobs (Johns et al. 2013). It is reasonable to believe that the potential impacts of ocean acidification on corals will also have great economic and environmental consequences for the state.

1. This document is FA220, one of a series of the School of Forest Resources and Conservation, Program in Fisheries and Aquatic Sciences, UF/ IFAS Extension. Original publication date March 2020. Visit the EDIS website at https://edis.ifas.ufl.edu for the currently supported version of this publication.

2. Joseph Henry, graduate student, Program in Fisheries and Aquatic Sciences, School of Forest Resources and Conservation; Joshua Patterson, assistant professor, Program in Fisheries and Aquatic Sciences, School of Forest Resources and Conservation, UF/IFAS Extension and Florida Sea Grant, The Florida Aquarium's Center for Conservation; and Lisa Krimsky, UF/IFAS Extension Florida Sea Grant Water Resources Regional Specialized Agent III, Southeast District; UF/IFAS Extension, Gainesville, FL 32611.

The Institute of Food and Agricultural Sciences (IFAS) is an Equal Opportunity Institution authorized to provide research, educational information and other services

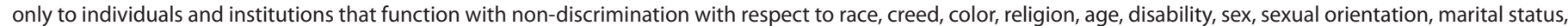

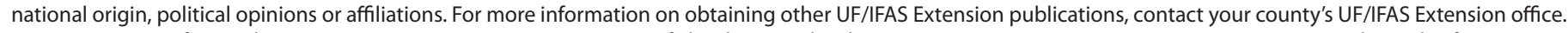
U.S. Department of Agriculture, UF/IFAS Extension Service, University of Florida, IFAS, Florida A \& M University Cooperative Extension Program, and Boards of County Commissioners Cooperating. Nick T. Place, dean for UF/IFAS Extension. 


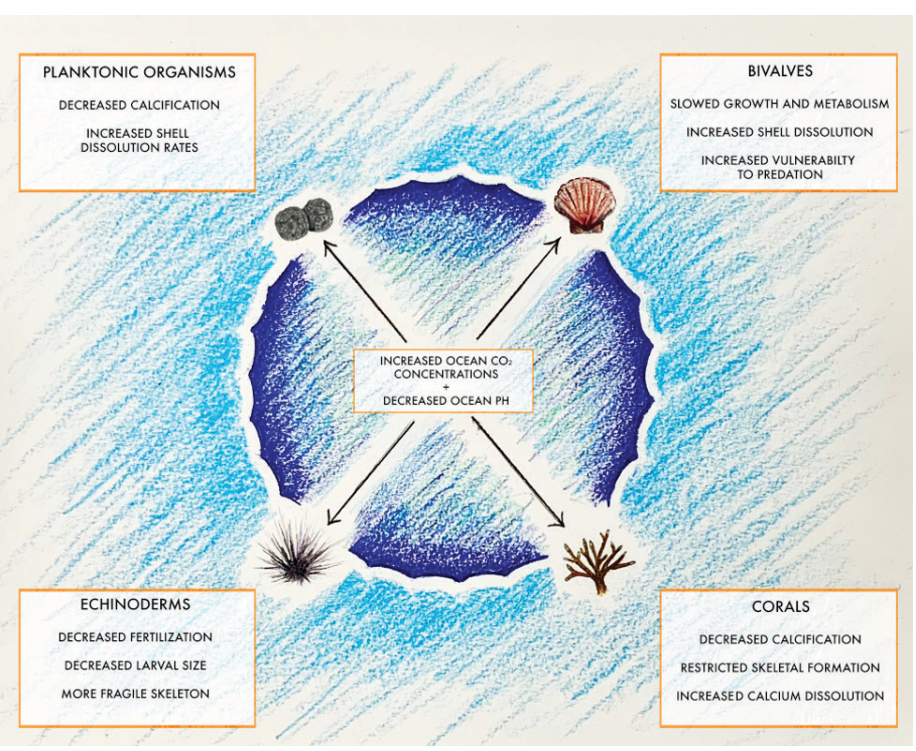

Figure 1. Impact of increased ocean carbon dioxide $\left(\mathrm{CO}_{2}\right)$ and decreased $\mathrm{pH}$ on planktonic organisms, bivalves, echinoderms, and corals.

Credits: Joseph Henry, UF/IFAS

Studies have shown that atmospheric $\mathrm{CO}_{2}$ levels of 560 ppm could decrease coral calcification by upwards of $40 \%$ as carbonate ion concentrations decrease and restrict skeletal formation (Hoegh-Guldberg 2007). Current levels are roughly 410 ppm (Lindsey 2019). Reduced pH has also been shown to escalate calcium carbonate dissolution rates (Kealoha et al 2019). Decreased calcification greatly impairs coral growth, which in turn diminishes the coral's ability to compete for benthic space against other marine species like macroalgaes (Gattuso 2011). A study by Muehllehner et al. (2016) found that the northernmost regions of the Florida Reef Tract are already "net erosional" with regards to calcification, meaning that the reef structure itself may be dissolving. Although some coral species have shown decreased calcification rates in response to ocean acidification, other coral species have not (Okazaki et al. 2017). Therefore, it is believed that impacts on coral calcification and growth result from a combination of factors including ocean acidification, temperature, light availability, and salinity (Kleypas 2005).

\section{Impacts on Bivalves}

Bivalves are a critically important group of aquatic organisms, and the state of Florida is home to a diverse assemblage of both freshwater and marine bivalves. Bivalves are aquatic mollusks including clams, oysters, mussels, and scallops. These organisms provide a multitude of ecosystem services. For example, the Eastern oyster (Crassostrea virginica) plays an important role in water filtration and the creation of habitat for fish and invertebrates in Florida (Grabowski and Peterson 2007). Furthermore, bivalves are economically important. In 2012, the hard clam industry in Florida supported 540 jobs and had an economic impact of $\$ 39$ million (Baker et al. 2015).

Some bivalve aquaculture and commercial fisheries have already been impacted by the effects of ocean acidification. In 2013, several oyster farmers in the Pacific northwest (a region where deep seawater upwellings create conditions of decreased water $\mathrm{pH}$ ) were forced to move their hatchery operations to Hawaii because declining ocean $\mathrm{pH}$ was killing oyster larvae and decreasing adult oyster yields (Welch 2016). Bivalves are vulnerable to increased $\mathrm{CO}_{2}$ concentrations and lower $\mathrm{pH}$, especially as larvae. Temporary fluctuations in $\mathrm{CO}_{2}$ may have little impact on these organisms, but long-term exposure to decreased carbonate availability and decreased $\mathrm{pH}$ has been shown to impact several biological processes that can lead to slower growth and reduced metabolism in mussels (Michaelidis 2005). Furthermore, ocean acidification can lead to shell dissolution in bivalves, impairing their overall growth and development. Shell dissolution is the breakdown and decomposition of the shell structure and has been observed in bivalves and other marine organisms. Although the full implications of increased dissolution rates are not clear, it is expected that degraded calcium carbonate shells could lead to reduced lifespans, higher susceptibility to predators, and other significant ecological consequences (Nienhuis 2010).

\section{Impacts on Echinoderms}

Echinoderms are one of the largest groups of marine organisms, and the group is widely represented in Florida. This group includes sand dollars, sea stars, sea cucumbers, brittle stars, crinoids, and sea urchins. Studies have begun to show the impacts of ocean acidification on echinoderms, specifically sea urchins. Due to their longer larval development times in the water column, sea urchins serve as an early indicator species for changing environmental conditions. A study that specifically observed the effects of increased $\mathrm{CO}_{2}$ concentrations found that increased $\mathrm{CO}_{2}$ concentrations can negatively affect the early life history of echinoderms by decreasing fertilization rates, early cell division, and size of planktonic echinoderm larvae (Kurihara 2004). Although not all adult echinoderm species appear to be profoundly impacted by ocean acidification, there are studies showing that mature urchins will be harmed by slowed development and degradation in skeletal integrity when exposed to the higher levels of ocean $\mathrm{CO}_{2}$ that are predicted by the middle/ end of this century (Albright 2012). 


\section{Impacts on Planktonic Organisms}

Marine plankton are small organisms that form the base of the marine food web. Plankton typically drift passively in the water column and are transported primarily by ocean currents. Not all plankton rely on calcification. However, many plankton species are significant calcifiers, and they are sensitive to OA. Globally, total calcification production in our oceans is dominated by the plankton community (Ribesell 2000), and coccolithophores, a single-celled type of phytoplankton, have been called "the world's single-most important calcifying organism" (Lohbeck et al. 2012). How OA will affect this group and what downstream effects it may render on marine ecosystems remain major questions. During their development, coccolithophores are suspended in the water column until their calcium carbonate skeletons are developed and they sink to the bottom. Increased $\mathrm{CO}_{2}$, resulting in changes to carbonate chemistry and decreased $\mathrm{pH}$, may decrease the calcification process in planktonic organisms and inhibit skeletal formation (Ribesell 2000). Furthermore, as altered carbonate chemistry leads to decreased available carbonate ions, it has been shown that dissolution rates increase in calcifying planktonic organisms, and shells can begin to dissolve under these conditions (Orr 2005). However, Lohbeck et al. (2012) suggest that adaptation to OA may occur over time in coccolithophores. Laboratory cultures exposed to OA for 500 clonal generations demonstrated calcification rates that were still lower than the non-OA control. However, these clonal populations showed $50 \%$ higher calcification rates than cultures exposed to OA for the first time.

\section{Conclusion}

Florida is home to many species that will be impacted by ocean acidification. Continued changes in carbonate chemistry and $\mathrm{pH}$ could lead to greater impacts on marine ecosystems and organisms (Kroeker 2010). Laboratory and in situ studies on calcifying organisms including corals, echinoderms, bivalves, and plankton have all shown negative impacts from increased oceanic $\mathrm{CO}_{2}$ concentrations and decreased $\mathrm{pH}$. These changes could lead to a multitude of problems that will harm other marine organisms, marine habitat structure, and the people who rely on these organisms and habitats for food, for livelihoods, and for protection against erosion and storm surge, among other threats. Changes in plankton populations could have negative impacts on food webs and ultimately reduce food availability for people. Furthermore, the erosion of coral reefs could leave coastal communities more vulnerable to the impacts of large storms as degraded coral reefs will no longer protect from high wave activity. Our current understanding of the impacts of ocean acidification on calcifying organisms is largely based on limited experiments that are performed in the laboratory. For this reason, it is important to recognize the complex nature of marine ecosystems and the importance of further studies that seek to better understand how ocean acidification may impact interactions within these dynamic ecosystems. There is still much to be understood about the long-term effects of changing ocean conditions on calcifying organisms and the impacts these changes will have on complex marine ecosystems. This publication primarily focused on the impacts of ocean acidification on calcification, but there are several other areas that could be affected by ocean acidification. To learn more about these, please refer to the other publications in the UF/IFAS Extension Ocean Acidification series.

\section{References}

Albright, R., C. Bland, P. Gillette, J. E. Serafy, C. Langdon, and T. R. Capo. 2012. "Juvenile Growth of the Tropical Sea Urchin Lytechinus variegatus Exposed to Near-Future Ocean Acidification Scenarios." Journal of Experimental Marine Biology and Ecology 426: 12-17. doi:10.1016/j. jembe.2012.05.017

Baker, S., K. Grogan, S. Larkin, and L. Sturmer. 2015. “'Green' Clams: Estimating the Value of Environmental Benefits (Ecosystems Services) Generated by the Hard Clam Aquaculture Industry in Florida." Gainesville: University of Florida Institute of Food and Agricultural Sciences $1-10, \mathrm{PDF}$

Gattuso, J. P., and L. Hansson. 2011. "Ocean Acidification: Background and History." In Ocean Acidification Gattuso \& Hanson (eds) 1-20. Oxford University Press Inc., New York.

Grabowski, J. H., and C. H. Peterson. 2007. "Restoring Oyster Reefs to Recover Ecosystem Services." In Ecosystem Engineers: Plants to Protists, Cuddington, Byers, Wilson, and Hastings (eds.) 281-298.

Hoegh-Guldberg, O., P. J. Mumby, A. M. Hooten, R. S. Steneck, P. Greenfield, E. Gomez, and N. Knowlton. 2007. "Coral Reefs under Rapid Climate Change and Ocean Acidification." Science 318(5857): 1737-1742. doi:10.1126/ science.1152509

Johns, G., C. Kelble, D. Lee, V. R. Leeworthy, and W. K. Nuttle. 2013. Ecosystem Services Provided by the South Florida Coastal Marine Ecosystem. Marine and Estuarine goal Setting (MARES) White Paper 20. 
Kealoha, A. K., K. E. Shamberger, E. Reid, K. Davis, S. Lentz, R. E. Brainard, and Y. M. Rii. 2019. "Heterotrophy of Oceanic Particulate Organic Matter Elevates Net Ecosystem Calcification." Geophysical Research Letters 46(16): 9851-9860. doi:10.1029/2019GL083726.

Kleypas, J. A., R. A. Feely, V. J. Fabry, C. Langdon, C. L. Sabine, and L. L. Robbins. 2005. "Impacts of Ocean Acidification on Coral Reefs and Other Marine Calcifiers: A Guide for Future Research." In Report of a Workshop Sponsored by the National Science Foundation, the National Oceanic and Atmospheric Administration, and the U.S. Geological Survey. Contribution No. 2897 from NOAA/Pacific Marine Environmental Laboratory.

Kroeker, K. J., R. L. Kordas, R. N. Crim, and G. G. Singh. 2010. "Meta-analysis Reveals Negative yet Variable Effects of Ocean Acidification on Marine Organisms." Ecology Letters 13(11): 1419-1434. doi:10.1111/j.1461-0248.2010.01518.x

Kurihara, H., and Y. Shirayama. 2004. "Effects of Increased Atmospheric $\mathrm{CO}_{2}$ on Sea Urchin Early Development." Marine Ecology Progress Series 274: 161-169. doi:10.3354/ meps 274161

Lindsay, R. 2019. "Climate Change: Atmospheric Carbon Dioxide." Anchorage Daily News. Retrieved October 28, 2019, from https://www. climate.gov/news-features/understanding-climate/ climate-change-atmospheric-carbon-dioxide

Lohbeck, K. T., U. Riebesell, and T. B. Reusch. 2012. "Adaptive Evolution of a Key Phytoplankton Species to Ocean Acidification." Nature Geoscience 5(5): 346-351. doi:10.1038/ngeo1441

Michaelidis, B., C. Ouzounis, A. Paleras, and H. O. Portner. 2005. "Effects of Long-Term Moderate Hypercapnia on Acid-Base Balance and Growth Rate in Marine Mussels Mytilus galloprovincialis." Marine Ecology Progress Series 293: 109-118. doi:10.3354/meps293109

Muehllehner, N., C. Langdon, A. Venti, and D. Kadko. 2016. "Dynamics of Carbonate Chemistry, Production, and Calcification of the Florida Reef Tract (2009-2010): Evidence for Seasonal Dissolution." Global Biogeochemical Cycles 30(5): 661-688. doi:10.1002/2015GB005327
Nienhuis, S., A. R. Palmer, and C. D. Harley. 2010. "Elevated $\mathrm{CO}_{2}$ Affects Shell Dissolution Rate but not Calcification Rate in a Marine Snail." Proceedings of the Royal Society of London B: Biological Sciences 277(1693): 2553-2558. doi:10.1098/rspb.2010.0206

Okazaki, R. R., E. K. Towle, R. van Hooidonk, C. Mor, R. N. Winter, A. M. Piggot, R. Cunning, A. C. Baker, J. S. Klaus, P. K. Swart, and C. Langdon. 2017. "Species-Specific Responses to Climate Change and Community Composition Determine Future Calcification Rates of Florida Keys Reefs." Global Change Biology 23(3): 1023-1035. doi:10.1111/gcb.13481

Orr, J. C., V. J. Fabry, O. Aumont, L. Bopp, S. C. Doney, R. A. Feely, A. Gnanadesikan, N. Gruber, A. Ishida, F. Joos, and R. M. Key. 2005. "Anthropogenic Ocean Acidification over the Twenty-First Century and Its Impact on Calcifying Organisms." Nature 437(7059): 681. doi:10.1038/ nature 04095

Riebesell, U., I. Zondervan, B. Rost, P. D. Tortell, R. E. Zeebe, and F. M. M. Morel. 2000. "Reduced Calcification of Marine Plankton in Response to Increased Atmospheric $\mathrm{CO}_{2}$." Nature 407: 364-367. doi:10.1038/35030078

Welch, C. 2016. "Ocean Acidification Drives Oyster Farmers to Hawaii." Anchorage Daily News. Retrieved August 4, 2019, from https://www.adn.com/ 